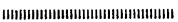
技術報告

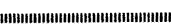

人工知能を応用した高炉操業管理エキス パートシステムの開発と適用

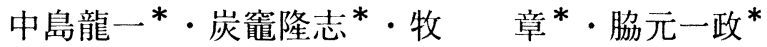 \\ 橋本絋吉 ${ }^{*} \cdot$ 酒井 敦 ${ }^{*} \cdot$ 桜井雅昭 ${ }^{*}$
}

\title{
Development and Application of Blast Furnace Operation Control Expert System Making Use of Artificial Intelligence
}

Ryuichi Nakajima, Takashi Sumigama, Akira Maki, Kazumasa WaKimoto, Kokichi Hashimoto, Atushi SAKAI and Masaaki SaKuraI

\section{Synopsis :}

A blast furnace operation control expert system (BAISYS) making use of artificial intelligence (AI) was developed and applied to the commercial operation of Fukuyama No. 5 blast furnace.

BAISYS gathers real-time information from numerous sensors installed on the blast furnace, and by using both this information and knowledge base in AI processor, which consists of knowledge and experience of operaters and engineers (experts), inference and judgement concerning furnace condition are performed and the optimum action is indicated.

The abnormal furnace condition diagnosis expert system, one of the two sub-system in BAISYS, predicts the probability of channeling and slip every two minutes and provides the forecast and action. The furnace heat control expert system, the other sub-system which is designed to constantly control the furnace heat level represented by the hot metal temperature, executes inference every 20 minutes.

This system is very effective for the stable operation of blast furnace.

Key words : artificial intelligence ; expert system ; blast furnace ; process control.

\section{1. 緒 \\ 言}

最近の高炉操業は, 溶銑, エネルギー需給の変化に即 応しつつ, 高品質溶銑の安定供給, 原燃料品質仕様の見 直し, 炉体寿命の延長など, 要求が多様化してきており, より高度な操業技術が求められている。

一方, 高炉プロセスの自動化, システム化は早くから 取り組まれ, 最新のエレクトロニクス技術やセンシング 技術が積極的に導入されてきた。 そして，これらの技術 の進歩とともに操業管理モデル ${ }^{112)}$ の開発が進められ, 操業技術の向上に貢献してきた。しかし，高炉のオンラ イン制御に関しては実操業で十分に機能しているモデル は少なく，操業技術者やオペレーターの判断に委ねる部 分が多く残つている.これは，高炉特有のさまざまな変 動, 外乱などの現象を数式モデルに組み込むことが難し いこと，従来の手続き型言語では，プログラムの保守， 改造に対する柔軟性がそしく新センサーの設置等により 情報形態や情報量が変化した場合に，システムの精度の
維持，们上が闲難であることによるものと思われる。 これらの問題を解決するため人知能 $(\mathrm{AI})$ の一分 野であるエキスパートシステム (ES) によるオンライ ン操業管理システム (BAISYS : Blast furnace Artificial Intelligence SYStem) を開発し， 2 次福山 5 高炉 (昭和 61 年 2 月 19 日火人れ, 内欲積 $4664 \mathrm{~m}^{3}$ ) に適用 した.

以下にシステムの概要と操業への適用結果について報 告する。

\section{2. エキスパートシステム博入の狙い}

高炉は，短期的には出銑涬状況の変化，原料性状の変 化，荷下がり状洗の变化等，また長期的には炉体プロ フィールの変化，装人物分布の变化等，常に何らかの外 乱が生じており，またそれらの外乱やアクションに対す る応答時間が遅いこと，過渡特性がその時々の状況によ り異なることなどから, 数式モデルの組立てによる操業 管理システムのみでは必ずしも満足すべき動的制御が得 
られているとは言いがたい。そのため, 現状, 安走な炉 況を維持し原料や操業等の諸条件の变動に対応する上 で, 高炉操業技術者の経験的な知識がなお重要な役割を 果たしている。

以上のような背景から，高炉操業管理へのエキスパー トシステムの適用においては次の 4 点を大きな狙いとし た.

\section{1)高炉操業技術の標準化と伝承}

2)高精度の操業管理システムの実現

3)操業者の愦判断の防止

4)システムの頻繁な改造要求に対する采軟な対応

\section{3. システム構成と特徵}

BAISYS は，異常炉洗診断エキスパートシステムと 炉熱制御エキスパートシステムの二つのサブシステムか らなつている.

本システムでは, Fig. 1 に示すようにプロセスコン ピューター(制御系) と AI 専用プロセッサー(推論系) の各機能を有機的に結合しオンラインリアルタイム処理 を実現している。すすおち, センサーデー夕の数値処理 は制御系（言語：FORTRAN）で行い，推論はバックエ ンド型の AI 専用プロセッサーにより LISP 言語を用い て実行している。このように，推論に必要な情報はオン ラインリアルタイムで収集，加Iされ，推論開始時には
すべて準備されているものを「センサーベース型オンラ インリアルタイムエキスパートシステム」と呼んでおり, 本システムの特徴の一つである.

\section{4. 異常炉況診断エキスパートシステム}

異常炉況診断 ES は，高炉に設置されている多数の センサー情報等をリアルタイムで自動的に収集し，これ らの情報と知識ベースに蓄えられた高炉操業技術者の知 識，経験を使用して，2 $\mathrm{min}$ 周期で吹き抜け・スリップ の発生する度合いの推論を行い, オペレーターに予報と してガイダンスし, その度合いにより減風のアクション を指示するものである.

\section{$4 \cdot 1$ 知識の表現}

一般に，エキスパートシステムでは，現象の事実，学 習，経験などにより得た知識を If (条件) Then（結論） でルール化して表す場合が多い。これは，プロダクショ ンルールと呼ばれている. 本システムでも以下の理由に より, 知識の表現にプロダクションルールを採用してい る.

1 ) 人間の思考過程との親和性があり知識の表現が容易 である。

2)状況認識-行動，あるいは前提条件-結論，の対であ らわされるので, 診断型問題解決システムに適してい $\gtrsim^{3)}$.

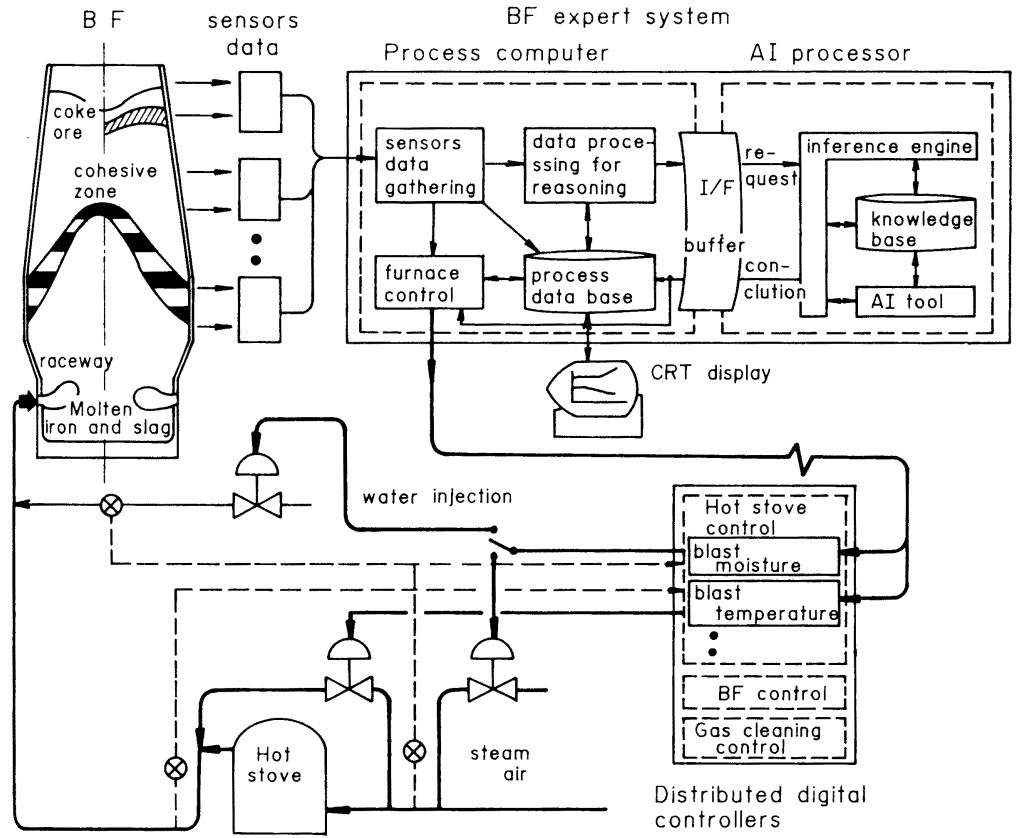

Fig. 1. System composition of BAISYS. 
3)新しい知識を断片的に付加できるのでシステムとし て段階的に成長することができる.

\section{$4 \cdot 2$ センサー情報の前処理}

本システムでは，例えば If（荷下がり速度が設定した しきい值より遅い）……というようなプロダクション ルールの条件部の判定を行うためセンサーデータをプロ セスコンピューター側で 2 段階の前処理を行つている.

すなわち, 今回使用した数百に及ぶセンサーデータは, 外乱や原料の装入の影響などによる変動を伴っており， これを除去するために，一次処理として統計的手段（最 小二乗法による一次回帰处理）を使つた平滑化を行つて いる. 二次処理では一次処理の結果にもとづき, 傾き, レベル, 変動量, 積分量などについておのおのの基準値 （しきい值）との比較を行うことにより，炬況変化につ ながるセンサーデータの特徵を抽出している.

\section{$4 \cdot 3$ 不確実な知識の取扱い}

従来の工学において, 不確実性は確率量によつて扱わ れてきたが，知識工学では，人間の思考過程の近似的実 現を目指すことから，理論的裏付けはないが人間の感覚 に適合する確実性指数が導入される場合が多い4). 本シ ステムでも知識のあいまいさを表すために確信度 (Certainty Factor; $C F$ 值）を導入した。

$C F$ 值は, $+1 \sim-1$ の範囲で設定することができ， その値の持つ意味は

$+1:$ 絶対的に正しい関係にある

$0:$ 無関係の場合

\section{$1:$ 完全に否定される場合}

である．総合した $C F$ 值の算出は（1)式で示すように， 一つ前までのルールの累積確信度と今回ルールの確信度 を結合関数占により統合して行つている.

$$
\begin{aligned}
C F_{t} & =\Sigma C F_{i} \\
& =\Sigma C F_{i-1}+\left(1-\Sigma C F_{i-1}\right) \cdot c f_{i}
\end{aligned}
$$

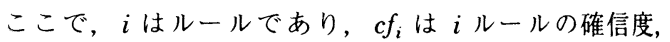
$C F_{t}$ は総合 $C F$ 值を示す. $C F$ 值の調整方法は, 現在決 定的な方法は確立されておらず各システムで最適な方法 を設計する必要がある。本システムでは，テストシステ ムを用いて，火入れ前は福山 2 高炬のデー夕，火入れ後 は蓄積された過去のデー夕により決定した。

\section{$4 \cdot 4$ 知識ベースの檕成}

異常炉況診断 ESに扔ける知識ベースの構成を Fig. 2 に示す．知識べースは約 200 のプロダクションルール からなり，それらは機能，七ンサーの属性により知識源 (Knowledge Source: KS) ごとに集合，ユニット化し, さらに階層化構造としている.

知識ベースは，七ンサ一情報から直接的に吹き抜け。 スリップを判定する KS 群と，吹き抜け・スリップに大 きな影響を与える残銑涬の状態を判定する KS 群なと から構成されている.

センサーより吹き抜け・スリップを判定するグルーナ では，内部の知識源を「荷下がり」,「温度」などのセン サーの属性ごとに分割している。 また，残銑涬判定 KS 群では, センサーデー夕判断 KS 群と人間判断 KS 群

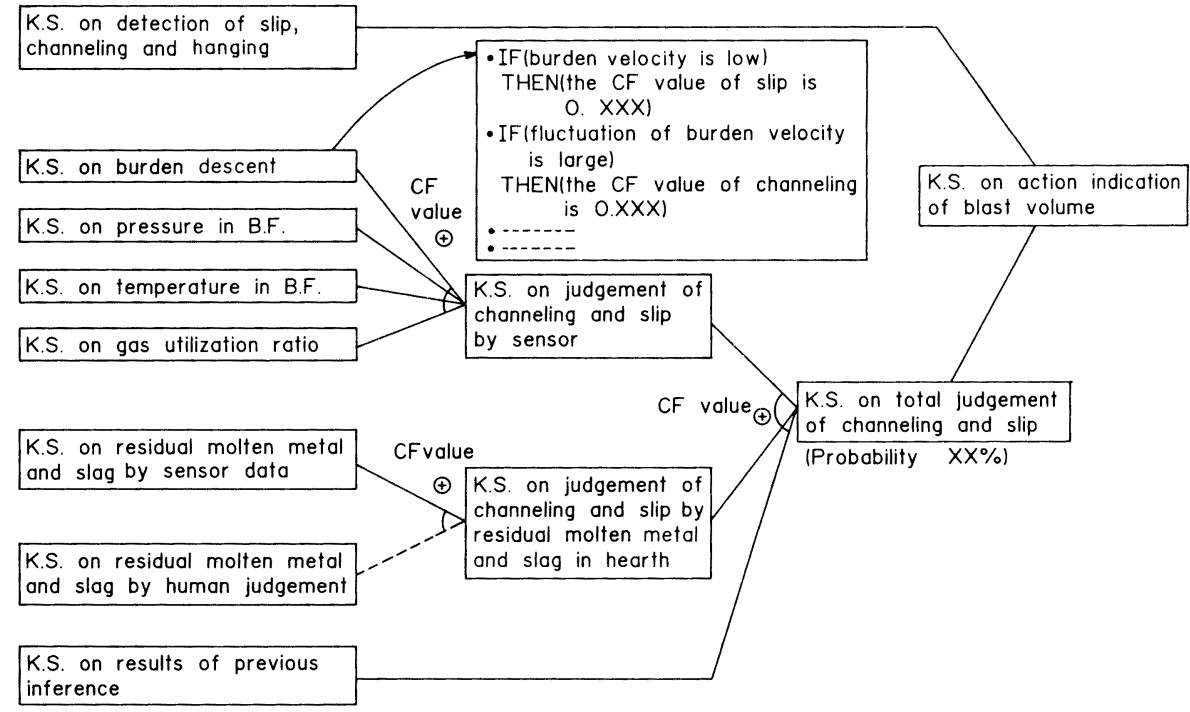

Fig. 2. Composition of knowledge base of abnormal furnace condition diagnosis expert system. 
とに分割している。ここで人間判断 KS 群は, 現状, センサーのみでは不十分な炉内残鉄涬貯留状況の把握を 人間判断により補填するもので，七ンサー情報より炉内 に残銑涬が発生したと判定した場合のみ起動し，対話形 式で入力することにより炉況の推論精度の向上を図つて いる.

異常発生検出ルールは，吹き抜け・スリップ・棚吊りを 検知するためのものである。

次に推論過程について概略説明する.

まず，二次処理したセンサーデー夕値がしきい值を超 えていればプロダクションルールの条件部が “真”と判 定され $C F$ 值が設定される。これらの $C F$ 值が各セン サーごとに前述の( 1 )式により累積加算され最終的にス リップ，吹き抜けの発生予知確率を求めている.

\begin{tabular}{|c|}
\hline Slip warning \\
Probability of occurrence is $63 \%$ at $12: 10$
\end{tabular}

\begin{tabular}{l}
$\begin{array}{l}\text { Results of diagnosis of slip are due to the } \\
\text { following reasons: }\end{array}$ \\
\multicolumn{2}{c}{ Reason } \\
- From burden descent judgement, \\
slip tends to occur \\
- From pressure loss judgement, \\
slip tends to occur \\
- From temperature judgement, \\
slip tends to occur \\
- Possibility of a large volume of \\
residual pig iron and slag is high \\
- Slip tends to occur (Sensor) \\
- Coefficient of effect of \\
previous slip warning probability \\
- Probability of occurrence of \\
slip this time
\end{tabular}

Fig. 3. Example of guidance on slip warning.
次に,この予知確率に基づいてアクション指示 $\mathrm{KS}$ により減風（量）等の取るべきアクションを決定する.

なお，スリップと吹き抜け予知に対するルールの基本 構成は同一であるが $C F$ 值を変えて対応している.

\section{$4 \cdot 5$ ガイダンス機能}

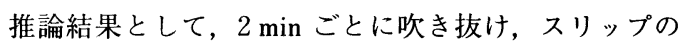
総合 $C F$ 值を CRT に表示するとともに, $C F$ 值がある 值以上になつた場合, オペレーターにスピークモニター でガイダンスする. また, 推論の経緯説明の表示と各種 中間推論結果の推移図を表示できる.これにより異常炉 況の理由, 場所等が診断結果としてオペレーターに告知 できるようになつている. それらの表示例を Fig. 3 に 示す.

\section{$4 \cdot 6$ 適用結果}

異常炉況予知に対する操業アクションとしては, 現状 吹き抜け発生予知確率 $\left(C F^{c}{ }_{t}\right)$ のランクにより減風基 準を次のように設定している.

$$
\begin{aligned}
& C F^{c}{ }_{t}=60 \sim 80 \% \Rightarrow \text { 送風流量 }-300 \mathrm{Nm}^{3} / \mathrm{min} \\
& C F^{c}{ }_{t}=80 \% \text { 以上 } \Rightarrow \text { 送風流量 }-500 \mathrm{Nm}^{3} / \mathrm{min}
\end{aligned}
$$

Fig. 4 は本システムの判定により減風し, 炉況異常 を回避した例である. 吹き抜け確信度が $60 \%$ を超えた ため減風 $300 \mathrm{Nm}^{3} / \mathrm{min}$ を行い, その結果, スリップは 生じたが吹き抜けには至らなかつた. その後, 吹き抜け, スリップ $C F$ 值の低下に合わせ増風し定常状態に回復 したものである.

Fig. 5 は, スリップに関する発生予知確率 $\left(C F^{s}{ }_{t}\right)$ と実際の発生率の関係を示したものであるが, $C F^{s}{ }_{t}$ が $60 \%$ 以上では $70 \%$ 以上の確率で実際にスリップが発生 していることがわかる. なお，スリップ実発生率は, 30 $\min$ ごとに $C F^{s}{ }_{t}$ の最大值を代表值として $10 \%$ きざみ

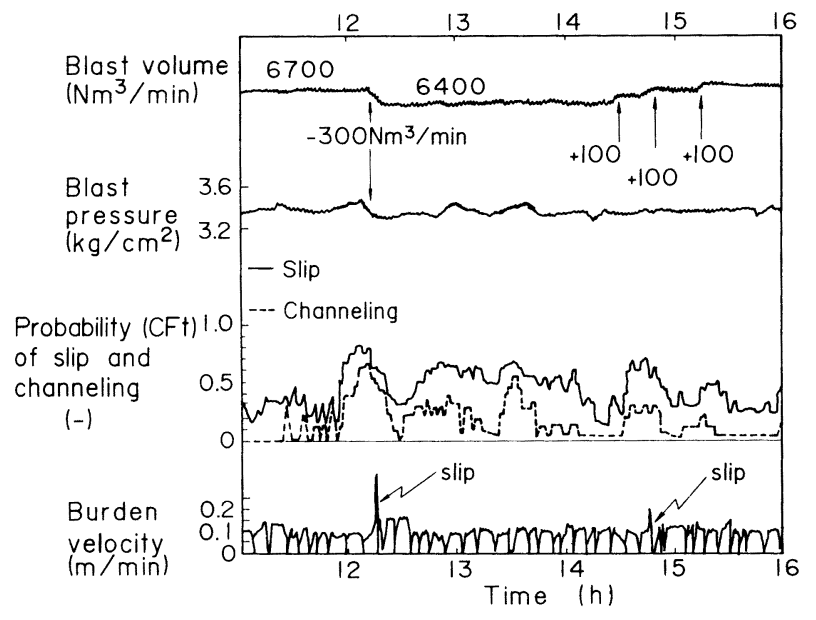

Fig. 4. Example of the operation by abnormal furnace condition diagnosis expert system. 
ごとに各 $C F$ レベルに割り振りデー夕採取期間内の各 $C F$ レベルの出現回数 $(N)$ と各 $C F$ レベル内のスリッ プ発生回数 $(F)$ との比 $(F / N)$ で表したものである.

このように，本システムの異常炉況予知に対する信頼 性は高く評価できることが示された。

なお，これらの判定結果 $\left(C F_{t}\right)$ は炉況指数として炉

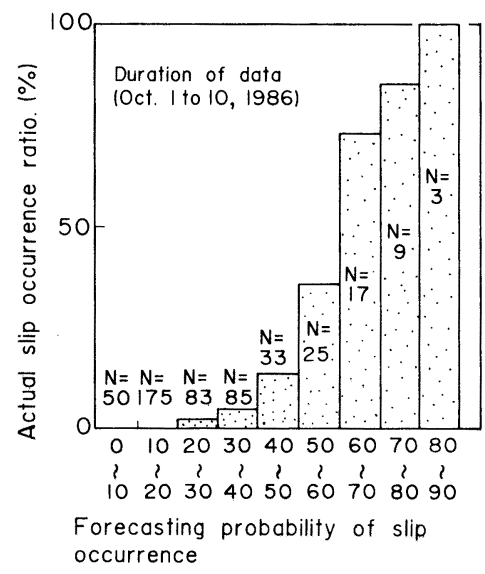

Fig. 5. Relation between the forecasting probability and the actual occurrence ratio for slip.
況の安定度も表しており長期的な炉況判断にも役立つて いる.

\section{5. 炉熱制御エキスパートシステム}

高炉操業管理上溶銑温度で代表される炉熱を一定状態 に管理することは, 溶銑の安定供給, 熱的効率の上昇, 高品質溶銑の生産などを行う上で最も重要である.これ を目的に開発された炉熱制御 ES では，20 minごとに 推論を行い必要なアクションを決定している.

\section{$5 \cdot 1$ 知識ベースの棏成と推論プロセス}

本システムの知識ベース構成を Fig. 6 に示す. 知識 の表現の大部分は, 異常炉況診断 ES と同様プロダク ションルールを用いているが, 一部フレームと LISP 関数も使用している. それらのルール数は約 550 であ る.

フレームには, 推論の材料となる䇥数值や, 炉熱の推 論結果から導かれる操作量などの事実型の知識が格納さ れている．また，LISP 関数は後述するあいまいさの表 現となる $C F$ 值の算出や, 各種の計算など手続き型知 識を記述している.

これらの知識ベースの内容を推論プロセスにそつて以 下に述べる。

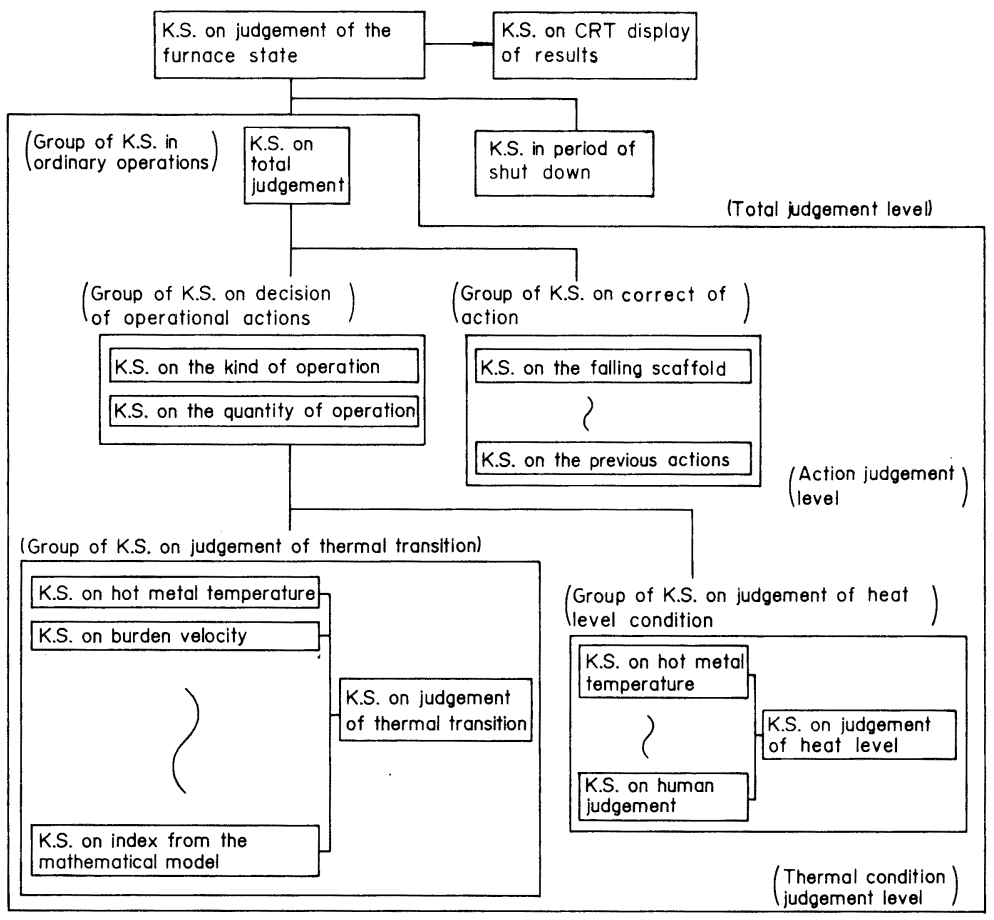

Fig. 6. Composition of knowledge bace of furnace heat control expert system. 
1)炉熱レベル判定 KS

推論開始時刻における炉熱の状態を判定する知識ベース である・

「溶銑温度」,「送風圧力」,「羽口埋込み温度」など, センサーの属性，機能に分割された KS 群からなつて おり，各 KS 群ごとに高〜低レベルまで 7 段階に分け られた炉熱レベルに対し, 次項で述べる方法で $C F$ 值 分布を求め, 最大確信度のレベルを現時刻の炉熱レベル としている．また，炉熱レベルが極度に低いと判定した 場合は, 羽口状況, 出銑状況などを任意の時刻に対話形 式で入力し，センサー関係ルールで得られない情報を取 りこむことができる人間判断ルールを有している.

なお, その他残銑滓貯留, 溶銑成分, 出銑口間温度偏 差，出銑形態などさまざまな条件に対応できる知識べー スで構成している.

2)炉熱推移判定 KS

炉熱推移を, 過去から現在に至る変化の度合いにより, 急上昇〜一定〜急降下の間で 5 段階にわけ各ランクごと に確信度をもとめ, その最大の值を示す段階を現時刻の 炉熱推移状態とする。

知識ベースは「溶鉄温度」をはじめとした各種セン サー類と,「溶銑成分」, などから構成されており，また， 「溶鉄温度」と「溶銑成分」については, さらに「短期 推移」および「長期推移」にわけてルール化している.

3)アクション判定 KS

現時刻の炉熱状態を炉熱推移と炉熱レベルを軸とした マトリックス上で求め, とるべきアクションを決定する. Photo. 1 は, その例を示す. 本例では $C F$ 值の頂点が, レベル $=5$, 推移 $=3$, にあり対応するアクションは $\mathrm{C}$ 型であることを示している。なお，マトリックス上の各

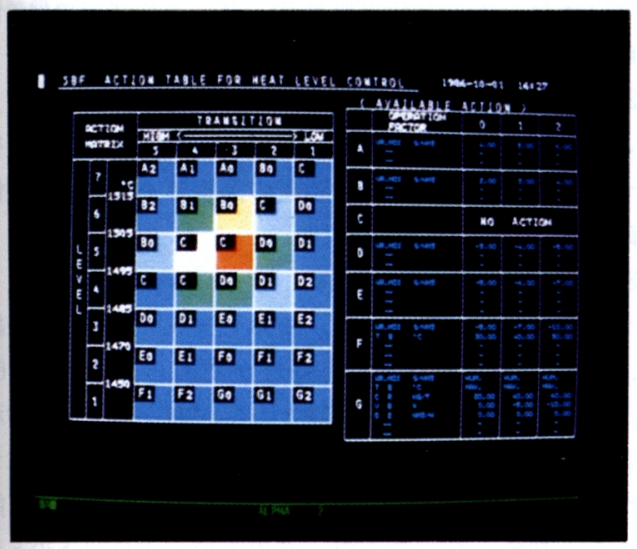

Photo. 1. Display of action table.
位置のアクション型および，アクション量は，あらかじ めフレームに知識として格納されている.

4)アクション補正量判定 KS

過去にとられたアクションあるいは外乱の判定をする とともに，それらの現時刻における影響量を考虑して補 正アクション量を決定する。その内容は, 送風湿度, 送 風温度, 液体燃料, コークス比などの操作量変更, およ びコークス水分，付着物脱落等の外乱などを検知して対 応するルールなどから構成されている.

例えば，送風湿度を変更した場合，その変更時刻と変 更量は「操作量変更検知」ルールで自動的に検出され， その後の影響量は「送風湿度」ルールにより時間の関数 として考慮される。また，炉壁付着物の脱落時には，「壁 落ち」ルールにより自動的に脱落個所と炉熱への影響量 および羽口先降下時間が判定され, 予備アクションの操 作時刻と操作量が決定され補正計算に組み込まれる。

5)アクション指示 $\mathrm{KS}$

1)４）の判定結果と操業方針に基づいて取るべきアク ション量をオペレーターに指示し，ガイダンスすると同 時に制御装置にフィードバックし完全自動制御を行うこ とが可能である. (Fig. 1 参照)

\section{$5 \cdot 2$ Fuzzy 集合理論の導入}

知識のあいまいさを表す手法として, 異常炉況診断シ ステムでは $C F$ 值を採用したが，本システムでは，さ らに，CF 值の決定方法にして，Fuzzy 集合の考え方 ${ }^{6)}$ を応用した 3 次元搪張メンバーシップ関数を導入した。

この理由は, メンバーシップ関数を導入しない通常の プロダクションルールにおいて, 関係するすべてのセン サーに対して, 例えば, (1)If (センサー $i$ の温度が $T_{1}$ 〜 $T_{2}$ の範囲である.) Then (高熱レベルである $C F$ 值

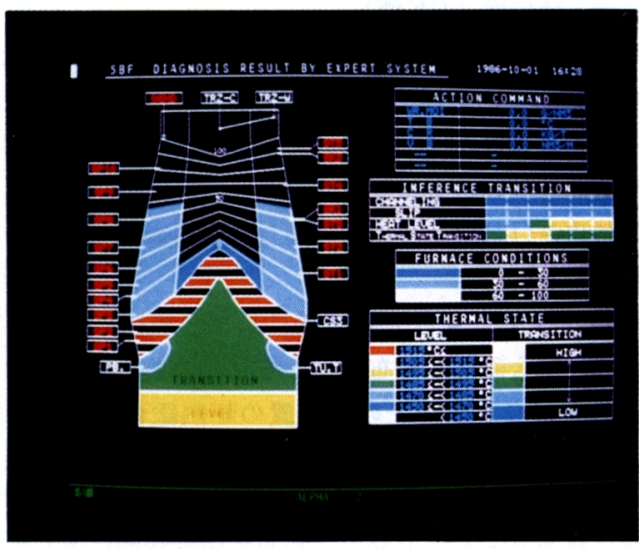

Photo. 2. Display of diagnosis results. 


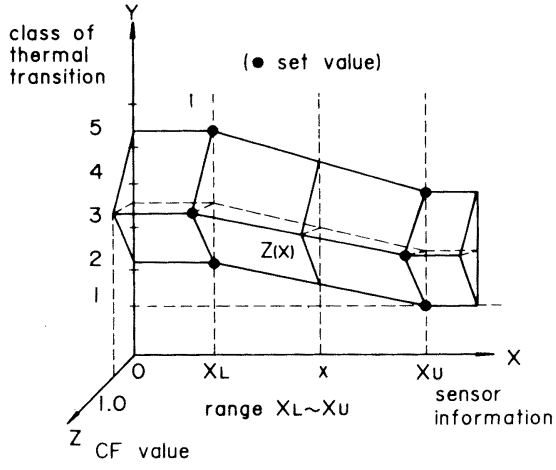

\begin{tabular}{c|l}
\hline Class & Description \\
\hline 5 & Steep ascent \\
4 & Ascent \\
3 & Leveling \\
2 & Descent \\
1 & Steep descent
\end{tabular}

Fig. 7. Example of membership function for thermal transition.

は $\left.C_{1}\right), \cdots \cdots,\left(\right.$ 低熱レベルである $C F$ 值は $C_{n}$ ); (2) If (センサー $i$ の温度が $T_{2} \sim T_{3}$ の範囲である.) Then (高 熱レベルの $C F$ 值は $\left.C^{\prime}{ }_{1}\right), \cdots \cdots($ 低熱レベルの $C F$ 値は $\left.C^{\prime}{ }_{n}\right)$; (3) ……ルールを表現していくと膨大なルール数 となり，推論時間が増大しかつ, $C F$ 值の調整が極めて 繁雑になる久点があると判断したためである.

Fig. 7 は，ある一つのセンサー情報に対する炉熱推 移のメンバーシップ関数を示したものである. 畄中（・） は，この関数の境界条件として与える入力值である.

$X \sim Z$ は,

$X$ 軸：一次処理デー夕（例えばソリューションロス カーボン量)

$Y$ 軸 : 炉熱推移状況 (変化の程度を 1 ～5 段階に区別)

$Z$ 軸 : 確信度 $(C F$ 值)

を意味する．ここでは，あるセンサーの值が $X$ 軸上 $x$ の時, Fig. 7 内に示す $Y$ 軸上の各段階 $(j=1 \sim 5)$ に対 する確信度 $Z_{j}(X)$ が求まることを表している。このよ うにして各情報ごとに確信度分布を求めた後, センサー ごとに重み付けをして累積加算し，推移総合確信度分布 を決定する。

炉熱レベルについても同様にして各段階 $(i=1 \sim 7)$ のレベル総合確信度分布を求める。このようにしてアク ションマトリックス上の各位置の炉熱総合確信度を求 め，前述したようにその最大值位置を現在の炉熱状況と する，なお，溶銑温度については，通常，出銑開始より 時間の経過とともに上昇し，やがて尘常状態に達して烟 熱を代表する值になる，そこで，遷移過程では溶銑温度
をそのまま使用すると䛊つた推論結果を導くおそれがあ る. 従つて, 溶銑温度が定常状態か遷移状態かを判定し, その状態に対忍したメンバーシップ関数を与えている. すなわち，あらかじめ出銑開始からの任意の時間におけ る溶銑温度とその夕ップ内最高温度の関係を統計的手法 を用いて解析し，遷移状態においても適切な炉熱レベル の判定ができるようにしている。

このように $C F$ 值の決走にに拡張メンバーシップ関数 を導入した結果，ルール数の膨張を防ぎ推論実行時間の 短緶とシステムメンテナンスの谷易化を実現できた。

\section{$5 \cdot 3$ ガイダンス機能}

$20 \mathrm{~min} こ ゙ と に$, 推論結果と最終アクション指示が CRTに表示される。な抄，自動制御連転時において， アクション変更される場命には，才ペレーターヘアナン シェータで注意を喚起する。

また，オペレーターの要求により，推論経緯の説明や 中閏推論絬果などの表ホも仃能である．Photo．2は BAISYSの総介判分表小例を亦す。

\section{$5 \cdot 4$ 実操業への適用}

システムを尖操業へ適用するにあたり，次の手順によ り進めた。

1)シミュレーション（䧈利 61 年 5 月〜）

2)オペレーションガイド（疁利 61 年 9 月〜)

3)オンライン陲制御武験（昭利 62 年 1 月〜 )

4)全自動制御の尖用化（町利 62 年 3 月 ）

1) シミュレーション

ここでは，まずオペレーターが適切にアクションを行 つている期開の操業デー夕を用いて，オペレーターと同 様な判定を小すように,テストシステムを用いて確信度， メンバーシップ関数，およびアクション操作量を決定し た。次にオペレーターの涢判断により邩熱の異常低下 や異常着熱を牛じた時の操業データにより判定の信頼性 を確認し，必要に心じてルールの追加を行つた。

2)オペレーションガイド

この期閵では，実際にオペレーターへガイダンスを行 いつつアクション補正，指小量の調整等を実施し信頼性 の们上を汹つた。

\section{3)オンライン自動制御試験}

シミュレーション䇽よび, オペレーションガイドの結 果，本システムの判断に仿効性が認められたので，62 年 1 月より自動制御化の試験として，本システムの指示 による、マニュアル制御を実施した。試験期間中の本シ ステムの適用率は $97 \%$ 以上であり，笔全自動化が可能 であると判断した。ここで，適用率の分義は以下のとお りである。 


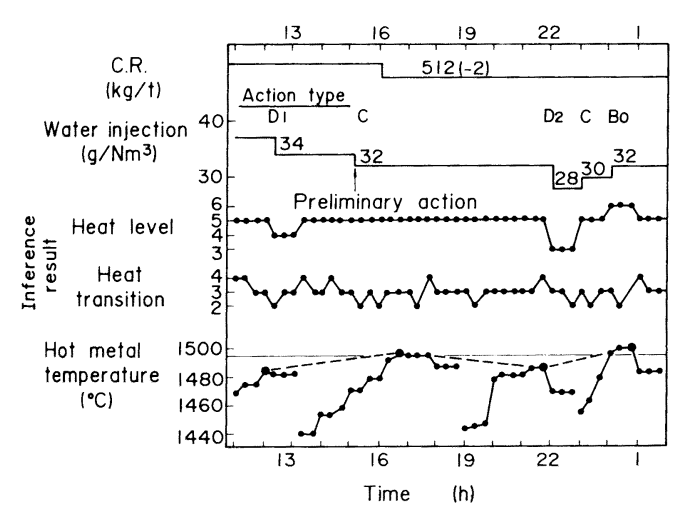

Fig. 8. Example of full automatic control of furnace heat by BAISYS.

\section{適用率 $(\%)=$}

$\frac{(\text { BAISYS の指示による実施回数) }}{(\text { BAISYS の指示回数) }} \times 100$

\section{4)全自動制御の奏施}

Fig. 8 に吹込み水比制御による自動制御実施後の操 業例を示す．たとえばアクション $D_{1}$ は，炉熱レベルの 低下（レベル $=4$, 推移=3）によるものである. $15 \mathrm{~h}$ のアクションは, 現時刻ではC 型（ノーアクション）で あるが, $16 \mathrm{~h}$ のコークス比 $-2 \mathrm{~kg} / \mathrm{t}$ に対する予備アク ションを考虑して取られたものである.

\section{6. 結言}

福山 5 高炉において，人工知能を応用した高炉操業管 理エキスパートシステム（BAISYS）を開発し実操業に 適用した。

本システムは, 異常炉況診断 ES と炉熱制御 ES の こつのサブシステムから成り, その特徵は,
1)センサーベースのオンライン・リアルタイム型エキ スパートシステムである

2)知識の表現はプロダクションルールを基本としてお り, 知識ベースのユニット化, 階層化により, ルール変 更, 追加の柔軟性, 推論実行の効率化を実現している.

3 )知識による判定のあいまいさを確信度で表現するこ とにより, 効率的な知識ベースの作成と, システム全体 の精度向上が可能となつている。なお，炉熱制御 ES では，CF 值の決定にFuzzy 集合の考え方に基づく拡 張したメンバーシップ関数を導入している.

本システムによる判定結果は非常に良好で異常炉況を 高い精度で事前に予知し, 回避することができることが 明らかになつた。また, 炉熱制御についてもシステム適 用率 $97 \%$ 以上を達成し, オンライン自動制御を実用化 した.

これらの結果, 次の効果が達成または期待されている.

1)操業管理の標準化

2)人間の誤判断の防止:

3 ) 温度, 成分変動の少ない高品質溶銑の次工程への安 定供給

4)炉冷の回避

5)省力化

\section{文献}

1 ）例えば, 羽田野道春, 的場祥行, 大场宏一, 芳木通泰, 宮本俊光: 鉄と鋼, 67 (1981), p. 528 など

2 ) 岡部俠児, 福武䦌, 高橋博保, 河合隆成, 岩村忠昭, 崎村 博: 川崎製鉄技報, 11 (1979), p. 34

3 ) P. H. WINSTON 著, 長尾 誠, 白井嘉明訳 : 人工知能 (1985), p. 147 [培風館]

4 ) 石塚 溝: 計測と制御, 29 (1984), p. 774

5 ) E. H. SHORTLIFFE: Computer-based medical consaltations (1976) [MYCIN. Now York, American Elsevier]

6 ) L. A. Zadeh: "Fuzzy Sets" Information and Contorol 8 (1965) 